\title{
REKONSTRUKSI PEMIKIRAN MULLĀ SADRĀ DALAM INTEGRASI KEILMUAN \\ Membangun Pendidikan Integratif Nondikotomik
}

\section{RECONSRTRUCTION OF MULLĀ SADRĀ THOUGHTS IN INTEGRATION OF KNOWLEDGE Building a Non-dichotomous Integrative Education}

\author{
Suparto dan Ahmad Zamakhsari \\ Fak. Dakwah dan Ilmu Komunikasi, Univ. Islam Negeri Syarif Hidayatullah Jakarta \\ Jl. Ir. H. Djuanda No. 95 Ciputat Tangeran Selatan \\ Email: suparto71@hotmail.com
}

\begin{abstract}
The integration of science and religion is an integrative-holistic integration meaning the existence of general science and religious studies depend on each other. The form of general science and religion with all their forms and character is essentially one and the same, what distinguishes it one from another is just the gradation (tashkik al-form) caused by differences in the essence. Mulla Sadra thoughts on the integration of science is embodied in the principle of Tawheed, then it is necessary to build an integrative educational concept of Islamic education that is designed as an education that is truly holistic and integrated in terms of vision, content, structure and processes and well integrated in its approach to the curriculum (how and what to teach), integrated knowledge and practice, applications and services. This holistic education includes philosophical and methodological concepts that are structured and coherent to the understanding of the world and all aspects of life. Religious knowledge based on revelation (the Qur'an and al-Hadith) is qauliyyah verses and general sciences based on senses, reasoning against natural phenomena is kauniyyah verses.
\end{abstract}

Keywords: Mulla Sadra, Integration, Holistic, Tawhid and Integrative Education

\begin{abstract}
Abstrak
Integrasi ilmu dan agama adalah integrasi yang bersifat integratif-holistik yaitu, eksistensi ilmu umum dan ilmu agama saling bergantung satu sama lain. Eksistensi (wujūd)yang ada pada pelajaran umum dan agama dengan segala bentuk dan karakternya pada hakikatnya adalah satu dan sama, yang membedakan satu dari yang lainnya hanyalah gradasinya (tashkīk al-wujūd) yang disebabkan oleh perbedaan dalam esensinya. pemikiran Mullä Sadrā tentang integrasi keilmuan yang tertuang dalam prinsip Tauhid, maka untuk membangun pendidikan integratif diperlukan Konsep pendidikan Islam yang dirancang sebagai pendidikan yang benar-benar holistik dan terpadu. Holistik dalam hal visi, isi, struktur dan proses. Terpadu dalam pendekatannya baik terhadap kurikulum (bagaimana dan apa yang harus diajarkan), pengetahuan yang menyatupadukan dengan praktik, aplikasi dan pelayanan. Pendidikan holistik inilah mencakup konsep filosofis maupun metodologis yang terstruktur dan koheren kepada pemahaman terhadap dunia dan seluruh aspek kehidupan. Ilmu-ilmu agama yang berbasis pada wahyu (al-Qur'ān dan al-Hadith) sebagai ayatayat qauliyyah dan ilmu-ilmu umum berbasis pada akal, penalaran terhadap fenomena alam sebagai ayat-ayat kauniyyah.
\end{abstract}

Kata Kunci: Mullā Sadrā, Integrasi, Holistik, Tauḥid dan Pendidikan Integratif

Naskah diterima 21 Juni 2015. Revisi pertama, 12 Juli 2015. Revisi kedua, 21 Juli 2015 dan revisi terahir 1 Agustus 2015 


\section{PENDAHULUAN}

Islam sebagai ajaran yang bersifat universal dan berlaku sepanjang zaman bukan hanya mengatur urusan akhirat, tetapi juga urusan dunia. Demikian pula Islam mengatur ilmu-ilmu yang berkaitan dengan Tuhan dan ilmu-ilmu yang berkaitan dengan keduniaan. Islam mengatur keduanya secara integrated. Di dalam alQur'ān dan as-Sunnah sesungguhnya tidak ada istilah ilmu agama dan ilmu umum, yang ada hanya ilmu itu sendiri dan seluruhnya bersumber dari Allah SWT. Apa yang disebut sebagai ilmu agama sebenarnya di dalamnya juga mengatur ajaran tentang bagaimana sesungguhnya hidup yang baik dan beradab di dunia ini dan apa yang disebut ilmu umum, sebenarnya amat dibutuhkan dalam rangka berhubungan dengan Tuhan. Namun, jika dilihat dari sifat dan jenisnya sulit dihindari adanya paradigma ilmu-ilmu agama dan ilmu-ilmu umum, atau paling tidak paradigma tersebut hanya untuk kepentingan teknis dalam mengklasifikasikan antara satu ilmu dengan ilmu lainnya. ${ }^{1}$

Hubungan ilmu (sains) dan agama, baik dalam ranah ontologis, epistemologis maupun aksiologis selalu menyisakan persoalan yang tidak pernah selesai dibicarakan. $^{2}$ Ilmu pengetahuan dewasa ini

${ }^{1}$ M. Hasbi Amiruddin dan Usman Husen. 2007. Integrasi Ilmu dan Agama. Banda Aceh: Yayasan PENA, h. 35 .

${ }^{2}$ Berawal dari temuan Copernicus (1473-1543) yang kemudian diperkuat oleh Galileo Galilei (15641642) tentang struktur alam semesta yang heliosentris (matahari sebagai pusat tata surya) berhadapan dengan gereja yang geosentris (bumi sebagai pusat tata surya), telah melahirkan ketegangan antara ilmu dan agama. Penerimaan atas kebenaran ilmu dan agama menjadi satu pilihan yang dilematis. Di mengalami dikotomisasi akibat gerakan sekularisasi barat sehingga ada pemisahan antara ilmu umum dan ilmu agama.Ilmu umum diidentikkan dengan ilmu yang sumber pengambilannya dari alam semesta, sedangkan ilmu agama yang bersumber dari wahyu, padahal semua itu berasal dari sumber yang sama yaitu Tuhan Yang Maha Esa karena wahyu dan alam semesta semuanya adalah ayat-ayat Allah, maka kalau melihat perkembangan ilmu pengetahuan dalam Islam tidak dijumpai adanya dikotomi antara ilmu keagamaan dan ilmu non keagamaan. ${ }^{3}$

Islam adalah agama yang memiliki berbagai macam pengetahuan, baik itu pengetahuan agama maupun pengetahuan umum. Dalam Islam pengetahuan tidak dibedakan, bahkan Islam menganggap kedua pengetahuan tersebut ibarat mata uang yang

Inggris pada tahun 1870 dalam satu kuliah umum Max Muller telah mengejutkan audiensnya ketika ia mempromosikan apa yang ia sebut sebagai ilmu agama (science of religion). Satu kombinasi yang pada saat itu dianggap aneh karena pasca Origin of Speciesnya Darwin, kebenaran ilmu dan agama semakin tidak dapat dipertemukan. Yang satu meyakini bahwa alam semesta terjadi karena diciptakan langsung oleh Tuhan (kreasionisme) dan yang lain menganggap alam semesta semata-mata merupakan proses alamiah yang sangat panjang (evolusionisme). Lihat Daniel L. Pals. 2001. Seven Theories of Religion, terj. Ali Noer Zaman. Yogyakarta: Penerbit Kalam. h. 6.

3 Dikotomi adalah pembagian dua bagian, pembelahan dua, bercabang dua bagian. Ada juga yang mendefinisikan dikotomi sebagai pembagian di dua kelompok yang saling bertentangan. Secara terminologis, dikotomi dipahami sebagai pemisahan antara ilmu dan agama yang kemudian berkembang menjadi fenomena dikotomik-dikotomik lainnya, seperti dikotomi ulama dan intelektual, dikotomi dalam dunia pendidikan Islam dan bahkan dikotomi dalam diri muslim itu sendiri (split personality). Lihat M. Rusydi, "Wacana Dikotomi Ilmu dalam Pendidikan Islam dan Pengaruhnya.” 2006. Jurnal: Al-Banjari,Vol.5, No.9. h: 23. 
memiliki dua sisi yang berbeda, namun tidak dapat dipisahkan satu sama lainnya. Dewasa ini,banyak orang yang sudah terbiasa dengan sebutan Ilmu Agama Islam dan Ilmu Umum.Ilmu Agama Islam yang berbasiskan pada wahyu, hadith Nabi, penalaran dan fakta sejarah sudah berkembang demikian pesat, misalnya Ilmu Kalām (Teologi) ${ }^{4}$, Ilmu

${ }^{4}$ Ilmu kalām (Teologi) termasuk ilmu Agama Islam yang paling pertama kali muncul dalam Islam. Kemunculan ilmu ini ada hubungannya denga peristiwa politik yang terjadi antara pasukan yang dipimpin Khalīfah Alī bin Abī Țalib (Khalīfah IV) dengan $M u$ 'āwiyah bin Abī Sufyan yang saat itu menjadi penguasa di Damaskus. Mu'āwiyah yang merasa memiliki pengaruh yang cukup besar di kalangan pengikutnya mencoba menghimpun kekuatan untuk memberontak melawan Khalifah Alī bin Abī Talib. Menghadapi yang demikian itu Alī bin Abī Țalib memutuskan untuk menumpas pemberontakan tersebut dan karenanya terjadilah peperangan disuatu tempat yang namanya Siffin. Peperangan yang hampir saja dimenangkan oleh pasukan Alī bin Abī Talib ini terpaksa dihentikan, karena dari pihak Mu'āwiyah menawarkan cara penyelesaian melalui damai (Arbitrase). Tawaran ini disetujui oleh Alī secara terpaksa, hingga secara politis pihak Alī bin Abī Țalib dikalahkan. Keadaan ini menyebabkan timbulnya kelompok yang tidak puas dan keluar dari Alì bin Abī Talib. Kelompok ini selanjutnya disebut Aliran Khawārij, Murji'ah dan berbagi aliran teologi lainnya. Dalam upaya saling menyalahkan atas kekalahan politis tersebut, alirannya tersebut menggunakan terminologi teologi, seperti Imān, kāfir, mushrik dan seterusnya. Perkembangan munculnya aliran teologi ini juga dipengaruhi oleh pemikiran filsafat yunani yang terjadi di zaman Abbasiyah. Atas pengaruh aliran filsafat ini munculah aliran Mu'tazilah, Ash'ariyah, Māturīdiyah dan sebagainya. Lihat Harun Nasution. 1978, Teologi (Ilmu Kalam). Jakarta: UI Press., Cet. 1, 45. dan Abuddin Nata, Ilmu Kalam, Filsafat dan Tasawuf. 1982. Jakarta: Rajawali, Cet. 1, 15-20.
fiqh(Ușūl fiqh) ${ }^{5}$, Filsafat ${ }^{6}$, Tașawuf ${ }^{7}$, Tafsīr (Ulūm al-Tafsīr) ${ }^{8}$, Hadith (Ulūm Hadith),

${ }^{5}$ Ilmu Fiqh (Ushul Fiqh) secara harfiah adalah ilmu yang membahas hukum-hukum shara' yang diproses melalui dalil-dalil terperinci. Ilmu yang amat "sibuk" mengatur hubungan manusia dengan Tuhan, hubungan manusia dengan manusia dan hubungan manusia dengan alam ini termasuk ilmu yang paling menonjol dan amat besar pengaruhnya dalam Dunia Islam. Sebagaimana dalam Ilmu Kalām, Ilmu Fiqh (Ușūl Fiqh) termasuk Ilmu yang sarat dengan nuansa perbedaan pendapat yang melelahkan. Lihat Abd. Wahab Khalaf. 1978. Ilmu Ushul Figh. Beirut: Dar alFikr. Cet. II, h. 34.

${ }^{6}$ Filsafat Islam adalah istilah yang mengacu kepada pemikiran-pemikiran filsafat yang ditulis oleh para filosof muslim, seperti al-Kindi, ar-Rāzi, al-Farābi, Ibnu Maskawaih dan Ibnu Sīna di dunia Islam belahan timur, serta Ibnu Bajjah, Ibnu Tufail, al-Ghazāli dan Ibnu Rushdy di belahan Barat. Filsafat Islam mulai muncul bersamaan dengan munculnya filosof muslim pertama, al-Kindi pada pertengahan abad ke-9 M (parohan pertama abad ke-3 H). Filsafat Islam mencapai puncaknya di tangan al- Farābi dan Ibnu Sina (abad ke-4 dan ke-5 H). Kedua filosof itu merupakan dua bintang terkemuka dalam filsafat Islam, sedangkan para filosof muslim lainnya dianggap sebagai satelit-satelitnya. Lihat Abdul Aziz Dahlan. 2012. Teologi, Filsafat, Tasawuf dalam Islam Jakarta: Ushul Press. h. 108.

${ }^{7}$ Tașawuf menurut bahasa Arab, berarti memakai pakaian dari șuf (bulu domba yang kasar, belum diolah) orang yang memakainya dapat disebut sufi atau mutașawwif. Memakai pakaian dari bulu domba yang kasar itu merupakan praktek yang lumrah dikalangan orang-orang miskin atau di kalangan mereka yang masa lalu (jauh sebelum datangnya Islam dan juga pada masa setelah datangnya Islam itu di abad ke-7 M). Lihat Abdul Aziz Dahlan. 2012. Teologi, Filsafat, Tasawuf dalam Islam, h. 169.

${ }^{8}$ Tafsīr (Ilmu Tafsīr) adalah ilmu yang membantu orang yang mempelajari untuk memahami kandungan al- Qur'ān secara benar sesuai dengan ajaran al-Qur'ān itu sendiri. Di dalam ilmu inipun banyak sekali cabang dan alirannya, ada yang bercorak teologi, falsafi, sufistik, fiqhiyah dan sebagainya. Lihat Abuddin Nata, Suwito, Masykuri Abdillah, Armai Arief. 2005. Integrasi Ilmu Agama dan Ilmu Umum Jakarta: PT RajaGrafindo Persada. h. 2. 
Sejarah dan Peradaban Islam, Pendidikan Islam, Dakwah Islamdan lain sebagainya.

Konferensi Pendidikan Islam Sedunia I di Makkah pada 1977 mengklasifikasikan ilmu kepada ilmu naqli(wahyu) dan ilmu 'aqli (dicari dengan akal). Ilmu aqli itu kemudian diklasifikasikan lagi kepada sains-sains alam (natural science) dan sains kemanusiaan (social science and humanities). ${ }^{10}$

Selanjutnya ilmu-ilmu umum yang berbasiskan pada penalaran akal dan data empirikjugamengalami perkembanganyang lebih pesat lagi dibandingkan dengan ilmuilmu agama Islam sebagaimana tersebut di dalam Islam. Ilmu-ilmu umum ini secara garis besar dapat dibagi kepada tiga bagian. Pertama, ilmu umum yang bercorak Naturalis dengan alam raya dan fisik sebagai objek kajiannya, yang termasuk kedalam ilmu ini antara lain; Fisika, Biologi, Kedokteran, Astronomi, Geologi, Botani dan sebagainya. Ilmu-ilmu tersebut selanjutnya disebut sains. Kedua, ilmu umum yang bercorak Sosiologis dengan perilaku sosial/manusia sebagai objek kajiannya, yang termasuk ke dalam ilmu ini antara lain; Antropologi, Sosiologi, Politik, Ekonomi, Pendidikan, Komunikasi, Psikologi dan sebagainya. Ketiga, ilmu umum yang bercorak Filosofis Penalaran, yang termasuk kedalam ilmu ini antara lain; Filsafat, Logika, Seni dan ilmuilmu Humaniora lainnya. ${ }^{11}$

\footnotetext{
${ }_{9}^{9}$ Abuddin Nata dkk, Integrasi Ilmu Agama \& Ilmu Umum, h. 2.

${ }^{10}$ Untuk laporan lebih lengkap tentang konferensi ini, lihat Hamid H. Bilgrami dan S. Ali Ashraf (Eds.). 1989., The Concept of Islamic University, terj. Machnun Husein dengan judul Konsep Universitas Islam. Yogyakarta: Tiara Wacana.

${ }^{11}$ Dewasa ini perkembangan ilmu pengetahuan umum bergerak amat cepat dan luar biasa sebagai akibat dari intensifnya kegiatan penelitian yang
}

Banyak faktor yang menyebabkan ilmu-ilmu tersebut tidak harmonis atau dikotomis. Pada inter ilmu agama misalnya, ketidak harmonisan tersebut banyak disebabkan oleh kepentingan politik kelompok, metode berfikir serta aliran yang diyakininya, situasi dan kondisi di mana seorang mujtahid berada, kecerdasan dan latar belakang pendidikan serta hubungan sosial lainnya. Sedangkan dalam inter ilmu umum perbedaan terjadi antara lain karena perbedaan metode dan pendekatan yang digunakan, situasi sosial politik, kecenderungan individual, kecerdasan dan keterbatasan pengetahuan, serta ideologi yang diyakininya. Adapun terjadinya dikotomi antara ilmu agama Islam dengan ilmu umum antara lain karena adanya perbedaan pada dataran ontologi, epistemologi dan aksiologi kedua bidang ilmu pengetahuan tersebut. Sebagaimana diketahui bahwa ilmu agama Islam bertolak dari wahyu yang mutlak benar dan dibantu dengan penalaran yang dalam proses penggunaannya tidak boleh bertentangan dengan wahyu. Sementara itu, ilmu pengetahuan umum yang ada selama ini berasal dari barat dan berdasar pada pendangan filsafat yang ateistik, meterialistik, sekularistik, empiristik, rasionalistik, bahkan hedonistik. Dua hal

didukung oleh etos ilmiah yang tinggi, dana yang berlimpah serta alat bantu penelitian yang canggih dan lengkap. Ilmu pengetahuan yang dahulunya dikuasai oleh umat Islam, kini sebagai besar dikuasai masyarakat Barat dan Eropa. Lihat Poeradisastra. 1980. Sumbangan Islam terhadap Peradaban Eropa dan Barat. Jakarta: P3M. Cet. 1, h.76.

Muhammad R. Mirza dan Muhammad Iqbal Siddiqi. 1986. Muslim Contribution to Science. Pakistan: Kazi Publications. Cet.1, h.17-29. 
yang menjadi dasar kedua ilmu ini jelas amat berbeda dan sulit ditemukan. ${ }^{12}$

Salah satu upaya untuk mengatasi keadaan tersebut adalah dengan cara mengintegrasikan intern ilmu agama dan intern ilmu umum, serta integrasi antara ilmu agama dengan ilmu umum. Upaya ini perlu dilakukan jika tidak menginginkan keadaan yang lebih membahayakan masa depan umat manusia. Upaya untuk mengintegrasikan ilmu agama dan ilmu umum tersebut mulai diperkenalkan para ahli yang visioner sejak akhir abad ke-20, yang menimbulkan pro-kontra. Di satu pihak ada yang setuju tentang Islamisasi ilmu ${ }^{13}$ tersebut dan di pihak lain ada yang tidak setuju. Sikap ini mirip dengan sikap yang ditunjukkan oleh umat Islam ketika merespons pelbagai masalah sosial politik. ${ }^{14}$

\footnotetext{
${ }^{12}$ Abuddin Nata dkk, Integrasi Ilmu Agama dan Ilmu Umum. h. 5-6.

${ }^{13}$ Islamisasi ilmu pengetahuan sering dipandang sekelompok pemikir hanya sebagai proses penerapan etika Islam dalam pemanfaatan ilmu pengetahuan dan kriteria pemilihan suatu jenis ilmu pengetahuan yang akan dikembangkannya. Dengan kata lain, Islam hanya berlaku sebagai kriteria etis di luar struktur ilmu pengetahuan. Asumsi dasarnya, bahwa ilmu pengetahuan adalah bebas nilai. Konsekuensi logisnya mereka menganggap mustahil muncul ilmu pengetahuan Islami, sebagaimana mustahilnya pemunculan ilmu pengetahuan Marxistis. Lihat Mulyanto, "Islamisasi Ilmu Pengetahuan," dalam Moeflich Hasbullah. 2000. Gagasan dan Perdebatan Islamisasi Ilmu Pengetahuan. Jakarta: LSAF, Iris, Cidesindo. Cet. 1, h. 17-18.

${ }^{14}$ Paling kurang terdapat tiga kelompok yang berpandangan berbeda-beda dalam merespons hubungan agama dan politik. Kelompok pertama, mereka yang mengatakan bahwa agama mengatur segala hal yang berkaitan dengan politik dan kenegaraan, sebagaimana diperlihatkan oleh Abul A'la al-Maudūdi, Hasan al-Bana dan lain-lain. Kelompok kedua, mereka yang mengatakan bahwa antara agama dan politik tidak ada hubungannya sama sekali. Agama mengaur hubungan manusia dengan Tuhan,
}

Sejarahmencatatbahwaperadaban Islam pernah menjadi kiblat ilmu pengetahuan dunia sekitar abad ke-7 M sampai abad ke$15 \mathrm{M}$. Setelah itu, masa keemasan itu mulai melayu, statis, bahkan mundur hingga abad ke-21 M ini. ${ }^{15}$ Ketika menjadi kiblat ilmu pengetahuan, pendidikan Islam yang berkembang adalah pendidikan Islam nondikotomis yang akhirnya mampu melahirkan intelektual muslim yang memiliki karya sangat besar dan berpengaruh positif terhadap eksistensi kehidupan manusia. Menurut Harun Nasution, ${ }^{16}$ cendekiawancendekiawan Islam tidak hanya mempelajari ilmu pengetahuan dan filsafat dari buku yunani, tetapi menambahkan ke dalam hasil-hasil penyelidikan yang mereka lakukan dalam lapangan ilmu pengetahuan dan hasil pemikiran mereka dalam ilmu filsafat. Dengan demikian, lahirlah ahli-ahli ilmu pengetahuan dan filosof-filosof Islam, seperti Ibnu Haytham (w. 1039) pelopor dibidang optik dengan kamus optiknya (kitāb al-Manażir), al-Tūsi (w.1274) astronom kawakan dari Damaskus yang melakukan penelitian tentang gerakan planet-planet, membuat model planet (planetarium), alFarāzi (astronom Islam), Ibnu Sīna (ahli kedokteran, sehingga dijuluki dengan doctor

sedangkan politik mengatur hubungan manusia dengan manusia, sebagaimana diperlihatkan oleh Ali Abd. Razak dan lain-lain. Kelompok ketiga, berpendapat bahwa agama memiliki hubungan yang erat dengan politik dalam hal memberikan prinsip-prinsip etis tentang ke arah mana politik tersebut dibawa. Lihat Munawir Sadzali. 1996. Islam dan Ketatanegaraan. Jakarta: UI Press. Cet.1, 34. A. Malik Fadjar. 2000. Reorientasi Pendidikan Islam. Jakarta: Grafiti. Cet. 1. h. 26-26.

${ }^{15}$ Syamsul Ma'arif. 2007. Revitasi Pendidikan Islam Yogyakarta: Graha Ilmu. h. 18

16 Harun Nasution. 1979. Islam Ditinjau dari berbagai Aspeknya. Jakarta: UI Press. h. 71. 
of doctors (Avicena), al-Bïruni (ahli filsafat, astronom, geografi, matematika, juga sejarah), Ibnu Rushdy (filosof dan ahli fiqh, sehingga dijuluki Averous), al-Khawārizmi (ahli matematika, sehingga dijuluki Algorismus), Ibn al-Haitham (ahli astronomi, sehingga dijuluki al-Hazen). Sedangkan dalam ilmu agama, terdapat para ulama yang mengembangkan ilmu hadith (Bukhāri Muslim abad ke-9 M), Ilmu hukum Islām (Imam Abū Hanīfah, Imām Mālik, Imām Shafi'i dan Ibn Hambal abad ke-7, ke-9) dan lain-lain.

Sementara itu, pada masa dan pasca alGhazāli ${ }^{17}$ (w. 1111 M) dan Ibnu Khaldun (w. 1406)mulailah terjadi diskursus dikotomi ilmu yang disebabkan oleh pendapat alGhazāli yang memandang sebagai fardu 'ain untuk menuntut"ilmu agama" dan "fardu kifāyah" untuk "ilmu-ilmu non agama" yang telah menimbulkan ketimpangan yang nyata antara kedua klasifikasi ilmu tersebut. ${ }^{18}$ Bukan itu saja al-Ghazāli pun dalam bukunya "Tahāfut al-falāsifah"

${ }^{17}$ Al-Ghazāli merupakan tokoh intelektual yang menjadi ikon khazanah keilmuan dalam Islam. Gelar yang disandangkan kepada al-Ghazāli seperti Hujjat al-Islām, Zain al-Dīn, Sharaf al-Ummah dan Mujaddid merupakan simbol pengakuan terhadap kebesaran namanya dan kapasitas keilmuannya sebagai salah seorang cendekiawan muslim ternama dalam sejarah. Kefenomenalannya tersebut membuat ia dianggap oleh banyak orang sebagai orang yang mempunyai otoritas keagamaan terbesar setelah Nabi Muhammad SAW. Bahkan, menurut al-Subki (w. $1370 \mathrm{H}$ ), seperti yang dikutip oleh Azyumardi Azra, yang mengatakan "Seandainya ada lagi Nabi setelah Nabi Muhammad, maka manusianya adalah al- Ghazāli". Lihat Azyumardi Azra. 2002. Historiografi Islam Kontemporer: Wacana, Aktualitas dan Aktor Sejarah Jakarta: Gramedia Pustaka Utama. h. 383.

18 Baharuddin, Umiarso, Sri Minarti. 2011. Dikotomi Pendidikan Islam; Historisitas dan Implikasi pada Masyarakat Islam. Bandung: PT Remaja Rosdakarya. h. ix. mengeluarkan fatwa-fatwa yang "membabi buta" hingga mengharamkan filsafat dan mengkafirkan orang yang mempelajari dan mengajarkannya. Ditangannya, dunia Islam dipenuhi dengan sisi mistis (tașawuf). Dalam hal ini, bagi Sayyed Hossein Nasr serangan al-Ghazāli terhadap filsafat dianggap telah melumpuhkan filsafat rasionalistik dan menghabisi karier filsafat sebagai disiplin yang berbeda dari gnosis dan teknologi di seluruh wilayah Arab pada dunia Islam. ${ }^{19}$ Walaupun sikap al-Ghazāli tersebut akhirnya mendapatkan jawaban dan serangan frontal dengan evaluasi kritis-akademis dari Ibn Rusdy dalam Tahāfut al-Tahāfut(rancu dalam kerancuan). Bahkan kalau dikaji secara "nakal", al-Ghazāli merupakan orang yang paling bertanggungjawab terhadap ambruknya kecemerlangan peradaban Islam, sehingga wajar jika orientalis Philip K. Hitti mencapnya sebagai orang anti intelektual. ${ }^{20}$

Di sisi lain, jika ditelusuri dari data sejarah, sebenarnya dikotomi terhadap ilmu tidak hanya terjadi di kalangan umat Islam itu sendiri, tetapi juga sudah terjadi sebelumnya, khususnya dikalangan umat Kristen dimasa kegelapan Eropa (the dark age). Pada masa itu eropa berada dalam

19 Seyyed Hossein Nasr. 1981. Islamic Life and Thought. Albany: SUNNY Press. h. 72. Sementara itu, pada karyanya yang lain Seyyed Hossein Nasr menyatakan bahwa sekalipun al- Ghazāli telah menyerang filsafat, namun pengarang Tahāfut alFalāsifah ini dianggap sebagai "filosof" juga. Kerena dia mengerti persoalan filsafat dan melakukan kritik atasnya secara filosofis. Meskipun membatasi ruang gerak rasionalisme Muslim, al-Ghazāli telah meratakan jalan bagi penyebar doktrin iluminasionis (ishrāqi) Suhrawardi (w. 587/1191) dan gnosis ('Iirfani) mazhab Ibnu 'Arabi (w.638/1240). Lebih detailnya lihat dalam Seyyed Hossein Nasr. 1968. Three Muslim Sages. Cambridge: Harvard University Press. h.55.

20 Philip K. Hitti. 1974. History of The Arabs. London: Macmilan Press Ltd. h.432. 
kekuasaan otoriter gereja, terutama setelah raja Roma constantine memeluk agama Kristen. Agama Kristen resmi menjadi agama negara dan agama yang berkuasa, sehingga lama kelamaan kekuasaan Paus dan pemuka agama kristen menjadi sedemikian besarnya, sehingga para raja di barat wajib tunduk kepada mereka, dan pada abad pertengahan ini manusia dianggap kurang dihargai, sedangkan kebenaran diukur berdasarkan ukuran dari Gereja (Kristen), bukan ukuran yang dibuat oleh manusia.

Pada stadium ini kemudian Paus dan pemuka-pemuka agama Kristen kala itu menetapkan beberapa teori ilmu pengetahuan dan mensucikannya menjadi teori atau bahkan postulat yang "kebenarannya tidak terbantahkan". Dengan otoritas yang dipaksakan melahirkan sikap otoriter dari gereja sendiri dalam menancapkan kukukuku kekuasaannya, sehingga siapa saja yang menentangnya akan menghadapi pengadilan di mahkamah Gereja (inkuisisi). Orang-orang yang diadili hingga mencapai 300.000 orang, 32.000 orang Di antaranya mendapatkan punisment dengan ganjaran dibakar hidup-hidup. Dia antara mereka terdapat dua ahli ilmu pengetahuan yang terkenal, yaitu Giordano Bruno dan Galileo Galilei.Giordano Bruno dianggap menentang gereja karena mengatakan bahwa alam ini banyak jumlahnya. Sedangkan Galileo Galilei mengatakan bahwa bumi berputar di sekitar matahari (Heliocentris). Kedua temuan ilmiah tersebut mendapat sambutan konfrontatif dari gereja yang mengindikasikan ototritas pengaruhnya takut terganggu oleh fakta tersebut. $^{21}$

21 Syahminan Zaini. 1989. Integrasi Ilmu dan Aplikasinya menurut Al-Qur'an. Jakarta: Kalam Mulia.
Disisi lain, ada ilmuan yang memiliki konsep dalam mengatasi dikotomi tersebut, ia adalah Mullā Sadrā ${ }^{22}$ tokoh yang hidup sezaman dengan Galileo Galilei (15641642). Artinya ketika di Barat sedang terjadi kebuntuan pemahaman tentang ilmu dan agama, Mullā Sadrātelah mempunyai konsep yang cemerlang untuk menjawab kebuntuan itu. Satu kondisi atmosfir keilmuan yang sangat kontras, karena di Barat sedang terjadi konfrontasi antara ilmu dan agama. Sedangkan di dunia Islam hubungan ilmu dan agama justru mengalami penguatan. Refleksi awal tentang pemikiran Mullā Sadrā dapat dikemukakan bahwa ia menempatkan ilmu dan agama tidak dalam posisi "konflik", keduanya mempunyai tolok ukur kebenaran sendiri tetapi kebenaran yang diperoleh tidaklah saling bertentangan. Metode yang digunakan untuk menemukan kebenaran ilmu dan agama bersifat kooperatif-saling mendukung. Ini terlihat dari pandangannya yang tidak menolak rasio dan empiris sebagai sarana untuk memperoleh kebenaran, Di samping ia juga menambahkan metode sufistik untuk mencapai kebenaran hakiki. Mullā Sadrā melakukan sintesis terhadap sumber pengetahuan yang meliputi iluminasi intelektual (kashf, dhauq atau ishrāq), penalaran atau pembuktian rasional ('aql, burhān, atau istiḍlāl) dan agama atau wahyu (shar'i atau wahy). ${ }^{23}$

h.7.

${ }^{22}$ Sadr al-Dīn Muhammad Ibnu Ibrāhīm, dikenal sebagai Mullā Sadrā, lahir di Shīraz (sekarang Iran) pada Tahun $979 \mathrm{H} / 1572 \mathrm{M}$ dan meninggal dunia pada tahun pada tahun 1050 H/1641 M. Lihat Mullā Sadrā. 1981. Al-Hikmah al-Muta'āliyah fï Asfar al-'Aqliyah alArba'ah. Beirut: Dār Ihyā wa al-Turāts Al'Arabī. h. 13.

${ }^{23}$ Syaifan Nur. 2002. Filsafat Wujud Mullā Sadrā. Yogyakarta: Pustaka Pelajar. h.5. 


\section{PEMBAHASAN}

\section{Hubungan Ilmu Agama dan IImu Umum dalam Perspektif Mullā Sadrā}

Apakah hubungan ilmu dan agama berada pada posisi konflik, independensi, dialog atau integrasi masih menjadi perdebatan hingga saat ini. Banyak kalangan mengambil sikap aman pada posisi independensi. Mereka berpendapat bahwa ilmu dan agama memang dua hal yang berbeda, baik metodologi, ukuran kebenaran dan tujuan yang hendak dicapai, sehingga menempatkan keduanya pada posisi saling tidak mencampuri urusan satu dengan yang lain menjadi pilihan yang terbaik. Pilihan dialog sekali-kali diambil manakala ada persoalan yang membutuhkan jawaban segera atau sementara ketika ilmu belum menemukan jawabannya. Di tengah kebimbangan untuk memahami pada posisi mana sesungguhnya ilmu dan agama berada. ${ }^{24}$

Konsep Mullā Sadrā secara ontologis terdiri atas tiga prinsip yang fundamental, yaitu: Wahdah al-Wujūd, Tashkïk al-Wujūd dan Așālah al-Wujūd. Mullā Sadrā mempunyai pandangan filosofis, terutama dalam bidang ontologi dan epistemologi yang memiliki karakter yang kuat pada tipe integrasi

${ }^{24}$ Secara umum terdapat tiga kajian penting filsafat, yaitu ontologi, epistemologi dan axiologi. Ontologi membicarakan keadaan sesuatu (metafisik), Epistemologi membicarakan sumber dan cara memperoleh sesuatu dan Axiologi membicarakan kegunaan dari sesuatu. Dalam filsafat Barat ketiga sudut pandang ini harus senantiasa dijadikan tolok ukur mengenai sesuatu. Misalnya A adalah titiktitik, bersumber dari titik-titik, diperoleh dengan cara titik-titik dan gunanya untuk titik-titik. Dengan cara ini keberadaan A akan diketahui secara utuh. Uraian yang relatif memadai terhadap ketiga bidang tersebut dapat dilihat pada; Jujun S. Suriasumantri. 1999. Filsafat Umum. Jakarta: Pustaka Sinar Harapan. h. 30 . meskipun secara eksplisit ia tidak pernah membahas secara langsung hubungan sains dan agama. Konsep Tauhìid Mullā Sadrā yang berimplikasi pada kesatuan ciptaan, yakni keterhubungan (interrelatedness) bagianbagian alam, dan selanjutnya berimplikasi pula pada kesatuan pengetahuan. Tauhìd bukan saja menjadi kerangka keimanan (frame of faith) yang menjadi dasar keyakinan umat Islam kepada Allah, namun juga merupakan kerangka pemikiran (frame of thought) yang membangun integrasi kebenaran. ${ }^{25}$ Pandangan Tauhīd ini didasarkan atas beberapa fiman Allah dalam alQur'ān, yaitu

"Dan Tuhanmu adalah Tuhan yang Maha Esa; tidak ada Tuhan melainkan Dia yang Maha Pemurah lagi Maha Penyayang”. (QS. Al Baqarah: 163)

"Berkata Rasul-rasul mereka: "Apakah ada keragu-raguan terhadap Allah, Pencipta langit dan bumi? Dia menyeru kamu untuk memberi ampunan kepadamu dari dosadosamu dan menangguhkan (siksaan)mu sampai masa yang ditentukan?" mereka berkata: "Kamu tidak lain hanyalah manusia seperti Kami juga. kamu menghendaki untuk menghalang-halangi (membelokkan) Kami dari apa yang selalu disembah nenek moyang Kami, karena itu datangkanlah kepada Kami, bukti yang nyata". (QS. Ibrāhīm: 10)

"Allah sekali-kali tidak mempunyai anak, dan sekali-kali tidak ada Tuhan (yang lain) beserta-Nya, kalau ada Tuhan beserta-Nya, masing-masing Tuhan itu akan membawa

${ }^{25}$ Mustofa, "Tauhid: Akar Tradisi Intelektual Masyarakat Muslim" dalam Intelektualisme Islam, Melacak Akar-akar Integrasi Ilmu dan Agama, editor Lutfi Mustofa dan Helmi Syaifuddin. 2007. UIN malang: LKQS. h. 12. 
makhluk yang diciptakannya, dan sebagian dari tuhan-tuhan itu akan mengalahkan sebagian yang lain. Maha suci Allah dari apa yang mereka sifatkan itu, Yang mengetahui semua yang ghaib dan semua yang nampak, Maka Maha Tinggilah Dia dari apa yang mereka persekutukan". (QS. Al-Mu'minūn: 91-92)

Keesaan Tuhan menurut Mullā Sadrā disebut sebagai ajaran "wahdah al-wujūd". ${ }^{26}$ Tentu saja konsep wah̆dah al-wujūd Mullā Sadrā ini diadopsi dari konsep sufi, khususnya Ibn 'Arabi (w. 1240). Tetapi, di antara keduanya terdapat beberapa perbedaan yang cukup mendasar. Berbeda dengan para teolog yang mengartikan kata "Ilāh"dalam formula "Lā Ilāha Illallāh"dengan "Tuhan yang wajib disembah", para sufi mengartikan kata "Ilāh" sebagai "hakikat" (realitas) sehingga bagi mereka "Lā Ilāha Illallāh"bisa berarti "tidak ada realitas yang betul-betul sejati kecuali Allah". Ibn Arabī mengatakan bahwa alam ini tidak lain daripada manifestasimanifestasi (tajalliyāt) Allah, atau lebih tepatnya manifestasi sifat- sifat, namanama, dan afäl Allah. Pada dirinya alam tidak memiliki realitas, Tuhanlah yang memberi realitas tersebut kepada alam. Tuhanlah satu-satunya realitas sejati, karena itu

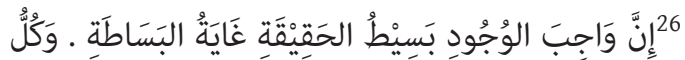

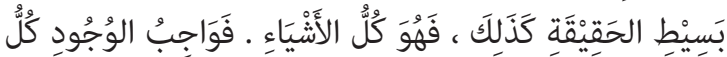

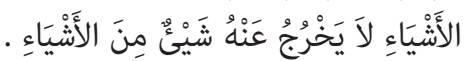

Wujud yang wajib ada bersifat murni, karena ada murni bersifat wajib ada, yang mencakup segala sesuatu dan tidak keluar dari-Nya sesuatu apapun/ tidak bisa dikaitkan dengan materi dan forma. Lihat Mullā Sadrā, Al-Hikmah Al-Mutä'aliyah fi' al-Asfär al-'Aqliyyah alArba'ah(Beirut: Dār Ihyā wa al-Turāth, 1981), Jilid 2, 49. mereka sebut Al-haqq (Sang Kebenaran, Sang Realitas Sejati).

Sejalan dengan itu, para filosof Muslim, khusus Ibn Sīnā juga mengatakan bahwa pada dirinya alam adalah mumkin al-wujūd artinya wujud-wujud yang mungkin dan dengan itu dia maksudkan sebagai wujud potensi. Jadi, dalam pandangan tokoh utama peripatetik Muslim ini pada dirinya alam hanyalah sebuah potensi bukan aktualitas, dan karena itu belum lagi memiliki realitas seperti yang kita lihat sekarang. Sebagai potensi, alam tidak bisa mewujudkan dirinya sendiri oleh dirinya. Ia membutuhkan (karena itu Suhrawardī menyebut alam alfaqir) wujud lain yang senantiasa aktual, yaitu Tuhan yang mandiri untuk keberadaannya. Jadi wujud alam bukanlah milik dirinya melainkan diberi Tuhan atau dipinjamkan Tuhan untuk suatu saat nanti diambil kembali. Dapat disimpulkan bahwa, baik bagi sufi maupun filosof pemilik sejati wujud adalah Tuhan, Dia-lah realitas sejati (al-haqq) menurut para sufi dan wajib wujud menurut para filosof, yang wujud-Nya senantiasa aktual. Sedangkan alam, apabila dilepaskan kaitannya dengan Tuhan hanya memiliki potensi murni yang oleh Aristoteles disebut dengan materi awal. ${ }^{27}$

Penjelasan Mullā Sadrā tentang waḥdah al-wujūd ini, tampaknya telah ia adopsi dari ajaran Suhrawardī Al-Maqtūl (w.1191) tentang cahaya. Menurutnya, cahaya pada hakikatnya adalah satu, tetapi ia menjadi berbeda-beda tingkat dan intensitasnya beda tingkat dan intensitasnya karena adanya barzakh-barzakh (barāzikh) yang menyela di antaranya. Dengan demikian, semakin jauh sebuah cahaya dari

${ }^{27}$ Mulyadhi Kartanegara. Integrasi Ilmu; Sebuah Rekonstruksi Holistik, h.34-35. 
sumbernya, yaitu Allah, sang Nūr al-Anwār, maka akan semakin redup sinarnya karena sebagian diserap oleh rangkaian barzakh yang amat panjang, yang seperti kaca riben dapat merambatkan cahaya itu pada yang di bawahnya, tetapi sebagian lagi teredam pada dirinya. Semakin jauh, semakin suram dan ketika mencapai alam materi maka cahaya itu pun telah hampir kehilangan sinarnya dan kegelapanlah yang kemudian mendominasinya. Dengan mengganti "cahaya" dengan "wujūd", Mullā Sadrā dapat dengan relatif mudah mengatakan bahwa wujud seperti halnya "cahaya" dalam filsafat Suhrawardi adalah satu dan sama dan hanya berbeda dalam derajat danintensitasnya oleh barzakh-barzakh pada hakikatnya adalah satu dan sama. Mereka berbeda hanya dalam gradasi disebabkan oleh modus tindakan esensi yang berbeda-beda. Wujūd tentu telah menimbulkan rangkaian wujud-wujud yang berbeda derajatnya, dari Tuhan, Sang Wujūd Murni, yang tentu saja bersifat immateriil (mujarad) melalui entitas-entitas immateriil lainnya yang lebih rendah (para malaikat) ke benda-benda langit (heavenly bodies) yang merupakan campuran antara benda-benda materi dan entitas-entitas immateriil (jiwa dan akal-akal dalam pengertian Avicenna) sampai ke benda-benda materiil seperti yang kita lihat di dunia fisik. Konsep kesatuan wujud telah mengintegrasikan berbagai wujūd yang berbeda-beda ini ke dalam kesatuannya yang kukuh dan memberi segala tingkat wujūd ini status ontologis mereka solid. Sehingga mereka tidak bisa dipisahkan dengan kategori riil dan tidak riil nyata atau ilusi. ${ }^{28}$

${ }^{28}$ Mulyadhi Kartanegara, Integrasi Ilmu; Sebuah Rekonstruksi Holistik, h.36. Lihat Juga Mulyadhi
Dengan demikian konsep "wahdah alwujūd"Mullā Sadrā dapat dijadikan sebagai basis integrasi ilmu, terutama bagi status ontologis objek-objek penelitiannya. Menurutnya, segala wujud yang ada dengan segala bentuk dan karakternya pada hakikatnya adalah satu dan sama yang membedakan satu dengan yang lainnya hanyalah gradasinya (tashkik al-wujūd) yang disebabkan oleh perbedaan dalam esensinya. Oleh karena itu, mereka pada dasarnya satu dan sama, wujud apapun yang kita ketahui yang bersifat spiritual atau yang materil tetntu mempunyai status ontologis yang sama-sama kuatnya dan sama-sama riilnya. Segala tingkat wujud boleh menjadi objek yang valid bagi ilmu, karena realitas ontologis mereka telah ditetapkan (fixed).

Integrasi antara ilmu dan agama. Ilmu dan agama bukan sesuatu yang terpisah dan bukan pula sesuatu yang berada di atas yang lain. Pandangan bahwa agama lebih tinggi dari ilmu adalah pengaruh dari konsep tentang dikotomi ilmu dan agama. Ilmu dianggap sebagai ciptaan manusia yang memiliki kebenaran relatif yang oleh karenanya memiliki posisi yang lebih rendah di banding agama sebagai ciptaan Tuhan yang memiliki kebenaran absolut. Dalam konteks gradasi Wujūd Sadrā, ilmu dapat bersifat absolut, demikian pula sebaliknya agama dapat bersifat relatif, tergantung keduanya berada pada tingkat gradasi yang mana. Dalam tingkat dunia Inteleksi ilmu bersifat absolut, karena kebenarannya menyatu dengan kebenaran Tuhan, demikian pula dalam tingkat dunia indera agama bersifat relatif, karena agama

Kartanegara. 2006. Gerbang Kearifan: Sebuah Pengantar Filsafat Islam. Lentera Hati: Jakarta. h. 72-73. 
dipahami sejauh yang mampu dikonsepsikan oleh manusia. Kesatuan ilmu dan agama berada pada tingkat dunia Inteleksi yang merupakan kebenaran Absolut. Pada tingkatan ini ilmu dan agama berada dalam kesatuan eksistensial, karena keduanya berada di dalam dan menjadi bagian dari Tuhan.

Integrasi antara ontologi, epistemologi dan aksiologi ${ }^{29}$ Dalam Islam dikenal konsep iman, ilmu dan amal. Konsep ini sebenarnya merupakan konsep teologis bahwa keimanan harus didasarkan atas ilmu dan diejawantahkan dalam amal perbuatan. Dalam bahasa lain sering di ungkapkan bahwa keimanan harus membuahkan ilmu yang amaliyah dan amal yang ilmiah. Konsep ini secara filosofis dapat memberikan gambaran tentang hubungan yang integratif antara ontologi, epistemologi dan aksiologi. Ontologi berbicara masalah ada (Wujūd), dalam Islam Wujūd tertinggi adalah Allah. Kenyakinan ontologis yang demikian itulah yang disebut dengan iman. Keyakinan bahwa Wujūd tertinggi adalah Allah akan memberikan corak keilmuan Islam religius, yang tidak memisahkan antara ilmu dan agama (aspek epistemologis). Kenyakinan ontologis dan epistemologis demikian juga akan mewarnai pandangan aksiologis bahwa ilmu tidak bebas nilai.

Dengan demikian, pada hakikatnya dalam konteks kesatuan Wujūd, tidak ada dikotomi antara ilmu Tuhan dan ilmu ciptaan manusia, karena dikotomi itu akan mengandaikan bahwa ada ilmu ciptaan manusia yang seakan-akan berada di luar

${ }^{29}$ M. Said Marsaoly, ia menulis artikel, "Pengetahuan dan Spiritualitas Berbasis Agama Sebuah Tinjauan Epistemologi," Mullā Sadrā Jurnal Filsafat Islam dan Mistisisme. 2011. Vol. 1, No. 4. h. 38. ilmu Tuhan. Adanya pembedaan ilmu naqliyah (berasal dari wahyu) dan aqliyah (berasal dari akal) tidak menunjukkan bahwa ilmu naqliyah adalah ilmu Tuhan sedangkan aqliyah adalah ilmu manusia. Namun konsep naqliyah dan aqliyah adalah konsep epistemologis cara bagaimana manusia menemukan kebenaran. Adapun ilmunya sendiri yang berupa ayat qauliyah dan ayat kauniyah, keduanya merupakan ilmu Allah. Manusia tidak memiliki ilmu tetapi menguasai ilmu (karena Allah berkuasa untuk mencabut ilmu yang dikuasai manusia). Demikia pula, tepat untuk dikatakan bahwa manusia bukan pencipta ilmu namun penemu ilmu.

Jelaslah kiranya bahwa konsep integrasi ilmu dan agama sesungguhnya berpusat pada Tuhan (tauhid),karena darinya semua berasal dan kepadanya semua aka kembali, inna lillāhi wa inna ilaihi rāji’un (segala sesuatu berasal dari Allah dan kepada-Nya semua akan kembali).

\section{Kerangka Pendidikan Holistik}

Visi pendidikan Islam telah membuat perbedaan tegas antara mengajarkan "hal-hal tentang Islam" (informatif) dan "bagaimana menjadi Muslim sejati" (transformatif). Tujuan dari pendidikan Islam bukanlah untuk memberi informasi tentang Islam kepada anak didik saja, tetapi lebih menekankan bagaimana menadi seorang muslim dan memberi mereka inspirasi sehingga ilmu tersebut bisa ditransformasikan dalam kehidupan mereka. Adanya perubahan paradigma dari pendidikan yang berorientasi pada informasi ke pendidikan yang berorientasi pada transformasi adalah esensial untuk 
dilakukan jika kita benar-benar berharap membangun paradigma baru pendidikan bagi pembangunan masyarakat muslim ideal. ${ }^{30}$

Reformasi yang menyeluruh amatlah dibutuhkan dalam sistem pendidikan di dunia Muslim. Adapun pendekatan ini berdasarkan pada empat komponen inti; Pertama, kerangka konseptual terpadu tentang pendidikan yang berdasarkan prinsip Tauhiddan pendidikan holistik. Kedua, tinjauan ulang terhadap tujuan pendidikan dan komponennya bagi pengembangan karakter (character development). Ketiga, merekonstruksi kurikulum atau gagasangagasan besar (powerfulideas) yang mempunyai kekuatan untuk mentransformasikan kepribadian. Keempat, penetapan ulang pengalaman mengajar dan belajar ke arah proses pembelajaran penemuan/pencarian (discovery learning).

Dalam tabel di bawah ini, penulis mengidentifikasi berdasarkan komponenkomponen pendidikan yang seharusnya

${ }^{30} \mathrm{Jika}$ kita menginginkan posisi yang penting dalam percaturan dunia saat ini, maka reformasi pendidikan mesti dilakukan. Reformasi akan membutuhkan pemikiran ulang dalam penstrukturan ulang elemen-elemen kunci dari sebuah lembaga pendidikan seperti kerangka konseptual, isi, struktur dan proses pendidikan. Perlu dicatat juga di sini bahwa usaha reformasi serupa juga sekarang lagi dilakukan oleh dunia pendidikan Barat. Tuntutan untuk menerapkan pendidikan yang holistik, pengajaran terpadu, pembelajaran kooperatif, pendidikan karakter, pembelajaran penemuan (discovery learning), dan penilaian otentik sangat banyak ditemukan dalam literatur pendidikan. Adapun konsep pendidikan Islam merupakan usaha untuk melakukan reformasi yang sesuai dengan tuntutan- tuntutan tersebut (dari model industri ke model humanis), yakni lebih natural, otentik dan efektif. Lihat M. Zainuddin, "Paradigma Pendidikan Islam Holistik,” Jurnal Ulumuna, Vol. XV, No. 1. 2011.: 83. ada dalam sistem pendidikan untuk dapat terwujudnya pendidikan holistik. ${ }^{31}$

Tabel 1: Komponen Pendidikan Holistik

\begin{tabular}{|c|c|c|}
\hline $\begin{array}{l}\text { Kompo- } \\
\text { nen }\end{array}$ & Senyatanya & Seharusnya \\
\hline Visi & $\begin{array}{l}\text { Pendidikan dianggap } \\
\text { sebagai disiplin } \\
\text { yang terpisah; } \\
\text { partikularistik, masih } \\
\text { memakai paradigma } \\
\text { mekanistik (model } \\
\text { perusahaan) }\end{array}$ & $\begin{array}{l}\text { Pendidikan dipandang } \\
\text { secara holistik } \\
\text { dan menyeluruh } \\
\text { berparadigma } \\
\text { rekonstruktif. }\end{array}$ \\
\hline Isi & $\begin{array}{l}\text { Pembelajaran } \\
\text { bersifat tradisional; } \\
\text { sekadar informatif, } \\
\text { tidak relevan dengan } \\
\text { kehidupan riil siswa } \\
\text { fokus pada instruksi/ } \\
\text { pengajaran textbook. }\end{array}$ & $\begin{array}{l}\text { Pembelajaran } \\
\text { bersifat modern, } \\
\text { transformatif, } \\
\text { realistik, kurikulum } \\
\text { berbasis kehidupan } \\
\text { riil }\end{array}$ \\
\hline Struktur & $\begin{array}{l}\text { Struktur tidak } \\
\text { koheren atau } \\
\text { disusun oleh disiplin } \\
\text { akademik yang rigid. }\end{array}$ & $\begin{array}{l}\text { Gagasan bersifat } \\
\text { poweful (powerful } \\
\text { ideas); mampu } \\
\text { memberi inspirasi } \\
\text { dan transformasi, } \\
\text { mampu membangun } \\
\text { kepribadian. }\end{array}$ \\
\hline Metode & $\begin{array}{l}\text { Didaktik (ceramah } \\
\text { dan kuliah); guru } \\
\text { sebagai pusat, satu } \\
\text { model untuk semua } \\
\text { siswa, tidak menarik } \\
\text { dan tidak inspiratif. }\end{array}$ & $\begin{array}{l}\text { Discovery learning; } \\
\text { terpusat pada siswa, } \\
\text { pengajaran bervariasi, } \\
\text { gaya pembelajaran } \\
\text { yang variatif, guru } \\
\text { sebagai penunjuk } \\
\text { (guide), modellling } \\
\text { dan mentoring, } \\
\text { model pembelajaran } \\
\text { terpadu/integrated } \\
\text { learning model (ILM) }\end{array}$ \\
\hline Program & $\begin{array}{l}\text { Terfokus pada masa } \\
\text { lampau 'tentang } \\
\text { Islam' sebagai } \\
\text { agama, ritual- } \\
\text { ceremonial. }\end{array}$ & $\begin{array}{l}\text { Life mastery; terpusat } \\
\text { pada hal-hal kekinian } \\
\text { 'tentang menjadi } \\
\text { Muslim; Islam sebagai } \\
\text { gaya hidup; Islam } \\
\text { untuk pemahaman } \\
\text { atau penguasaan } \\
\text { hidup/Is/am for Life } \\
\text { Mastery (ILM) }\end{array}$ \\
\hline
\end{tabular}

31 M. Zainuddin. 2007. Paradigma Pendidikan Terpadu: Menyiapkan Generasi Ulūl Albāb. Malang: UIN Press. h. 97. 


\begin{tabular}{|l|l|l|}
\hline Tujuan & $\begin{array}{l}\text { Perolehan informasi } \\
\text { ansich, pengetahuan } \\
\text { dan keterampilan } \\
\text { hanya untuk } \\
\text { perolehan pekerjaan }\end{array}$ & $\begin{array}{l}\text { Beyond schooling; } \\
\text { bagaimana belajar } \\
\text { (how to learn), } \\
\text { pembelajaran } \\
\text { seumur hidup, } \\
\text { pengembangan } \\
\text { manusia seutuhnya }\end{array}$ \\
\hline Penilaian & $\begin{array}{l}\text { Tes formal } \\
\text { berdasarkan buku, } \\
\text { benar atau salah, } \\
\text { lulus atau tidak lulus, } \\
\text { tes standar. }\end{array}$ & $\begin{array}{l}\text { Authentic } \\
\text { assessment; tugas } \\
\text { otentik, berhubungan } \\
\text { dengan dunia riil, } \\
\text { penilaian bersifat } \\
\text { multi intelligensi }\end{array}$ \\
\hline
\end{tabular}

Wilayah pertama yang perlu direformasi adalah visi atau kerangka konseptual pendidikan secara menyeluruh. Pendidikan bermula dari prinsip Tauhidd(keutuhan dan keterpusatan pada Tuhan). Hal inilah yang menjadi dasar pijakan dalam pandangan dunia pendidikan. Prinsip Tauhìdmencakup konsep filosofis maupun metodologis yang terstruktur dan koheren terhadap pemahaman kita terhadap dunia dan seluruh aspek kehidupan. Tauhidmengajarkan kita untuk menghimpun pandangan yang holistik, terpadu dan komprehensif terhadap pendidikan. ${ }^{32}$ Pendidikan modern (baik Islam maupun Barat) secara umum berdasarkan pandangan pendidikan yang tidak koheren dan parsial. Akibatnya, siswa dan guru jarang sekali punya pandangan yang sama tentang proses pendidikan secara menyeluruh. Kebanyakan siswa meninggalkan sekolah sekitar umur 13-17 tahun tanpa mempunyai tujuan hidup yang jelas, bahkan yang mereka pikirkan hanya mendapatkan kerja. Lebih dari itu, prinsip Tauhidmenuntut para pendidik mempunyai pandangan yang menyeluruh dan tujuan sejatiterhadap pendidikan dan kehidupanitu sendiri. Oleh karena itu, konsep Tauhìdharus

${ }^{32}$ M. Zainuddin, ia menulis artikel "Paradigma Pendidikan Islam Holistik," Jurnal Ulumuna, Vol. XV, No. 1. 2011. h. 85. menjadi landasan tentang bagaimana kita mendidik anak, termasuk apa yang diajarkan (isi), bagaimana kita mengorganisir apa yang harus diajarkan (struktur), dan bagaimana kita mengajarkannya (proses). Akhirnya, Tauhidharuslah membentuk fondasi pemikiran, metodologi dan praktik pendidikan kita.

Konsep pendidikan Islam mestilah dirancang sebagai pendidikan yang benarbenar holistik dan terpadu. Holistik dalam hal visi, isi, struktur dan proses dan terpadu dalam pendekatannya baik terhadap kurikulum (baik bagaimana dan apa yang harus diajarkan), pengetahuan yang menyatupadukan dengan praktik, aplikasi dan pelayanan. Konsep ini menegaskan bahwa aspek-aspek integratif secara signifikan akan meningkatkan kekuatan, relevansi dan keefektifan pengalamanbelajar dan mengajar. Konsep ini mengadvokasikan pendekatan holistik dalam pendidikan.

Tabel 2: Aspek Holistik Pendidikan

\begin{tabular}{|l|l|}
\hline Aspek Holistik & Contoh \\
\hline Tujuan & $\begin{array}{l}\text { Pembelajaran seumur hidup, } \\
\text { bersifat komprehensif, menjadikan } \\
\text { anak didik sebagai khairu ummah. }\end{array}$ \\
\hline $\begin{array}{l}\text { Pandangan } \\
\text { Terhadap Anak }\end{array}$ & $\begin{array}{l}\text { Pemahaman anak secara utuh; } \\
\text { pikiran, tubuh, jiwa, multi } \\
\text { intelegensi, dan juga gaya belajar. }\end{array}$ \\
\hline $\begin{array}{l}\text { Apa yang harus di } \\
\text { ajarkan }\end{array}$ & $\begin{array}{l}\text { Gagasan yang poweful dan } \\
\text { pertanyaan-pertanyaan brillian } \\
\text { terhadap dunia secara utuh } \\
\text { (multikultural). }\end{array}$ \\
\hline $\begin{array}{l}\text { Bagaimana } \\
\text { mengorganisir }\end{array}$ & $\begin{array}{l}\text { Kurikulum terpadu; pembelajaran } \\
\text { integrated. }\end{array}$ \\
\hline $\begin{array}{l}\text { Bagaimana } \\
\text { mengajarkannya }\end{array}$ & $\begin{array}{l}\text { Sesuai dengan kemampuan anak } \\
\text { didik, pengajaran yang bervariasi, } \\
\text { pemanfaatan lingkungan. }\end{array}$ \\
\hline
\end{tabular}


Adapun prinsip Tauhid (holistik, terpadu, terpusat pada Tuhan) adalah prinsip dasar dari pendekatan tarbiyah. Selain itu, terdapat sejumlah prinsip lainnya yang mendukung terbentuknya kerangka teoritis dari pendekatan tersebut. Beberapa prinsip itu berasal dari adanya perenungan terhadap proses pertumbuhan dan perkembangan alam..$^{33}$ Prinsip Tauhìdyang dituangkan melalui konsepWahdah alWujūd Mullā Sadrā sangat berguna untuk mengafirmasi status ontologis objek-objek ilmu yang dalam tradisi ilmiah barat hanya dibatasi pada objek-objek fisis atau empiris dengan alasan bahwa hanya objek-objek fisiklah yang status ontologisnya tidak bisa diragukan karena bisa ditngakap oleh indera, sedangkan objek-objek lainnya yang nonfisik diragukan satatus ontologisnya karena tidak bisa ditangkap oleh indera. Dengan demikian, epistemologi Islam telah mencoba mengintegrasikan seluruh sumber ilmu yang bisa dimiliki manusia dalam satu kesatuan yang utuh dan holistik. ${ }^{34}$

\section{Kurikulum Berbasis Integrasi}

Kurikulum dan pembelajaran merupakan dua hal yang tidak dipisahkan walaupun keduanya mempunyai kedudukan dan

${ }^{33} \mathrm{M}$. Zainuddin, ia menulis artikel "Paradigma Pendidikan Islam Holistik," Jurnal Ulumuna, Vol. XV, No. 1. 2011. h. 86.

${ }^{34}$ Prinsip wahdah al-wujūd dalam filsafat Sadrā ini yang melihat kesatuan wujud terbentang lebar pada segala apa yang disebut sebagai "sesuatu", mulai dari wājib al-wujūd sampai ke mumkin alwujūd (contingent beings) yang beraneka ragam dan bervariasi. Prinsip ini pada akhirnya melahirkan prinsip lain yang dikenal dengan istilah tashkik alwujūd atau graditas wujud. Lihat Mullā Sadrā, AlMasā'il al-Qudsiyyah; Mutashābihāt al-Qur'ān (Resāle: Masyhad University Press, tth), 5. fungsi yang berbeda. Suatu rencana atau program kurikulum tidak akan bermakna manakala tidak diimplementasikan dalam pembelajaran. Sebaliknya tanpa kurikulum yang jelas maka sejatinya pembelajaran tidak akan berlangsung secara efektif. Hal ini sesuai yang dikemukakan oleh Saylor, Alexander dan Lewis, "Without a curriculum or plan, there can be no efektive instruction and without instruction the curriculum has little meaning". Landasan pokok penyusunan kurikulum islami harus memuat prinsip: a) Mengandung nilai kesatuan dasar bagi persamaan nilai Islam pada setiap waktu dan tempat.b) mengandung nilai kesatuan kepentingan dalam mengembangkan misi ajaran Islam.c) mengandung materi yang bermuatan pengembangan spiritual, intelektual dan jasmaniah. ${ }^{35}$

Bertolak dari rumusan UU Sistem Pendidikan Nasional RI No. 20 tahun 2003 pasal 339, yang mengisyaratkan bahwa tujuan pendidikan Indonesia mengarahkan warganya kepada kehidupan yang beragama. Maka sebagai salah satu bentuk realisasi dari UU Sisdiknas tersebut, Integrasi adalah alternatif yang harus di pilih untuk menjadikan pendidikan lebih bersifat menyeluruh (integral-holistik). Gagasan integrasi (nilai-nilai islami/agama dan umum) ini bukanlah sebuah wacana untuk meraih simpatik akademik, melainkan sebuah kebutuhan mendesak yang harus dijalankan sebagai pedoman pendidikan yang ada, mengingat pendidikan selama ini dipengaruhi oleh dualisme yang kental antara ilmu-ilmu agama dan ilmu-ilmu

35 Saylor, J. Galen, Alexander, William M. dan Lewis Arthur J. 1981. Curriculum Planning For Better Teaching and Learning. New York: Holt-Rinchart and Winston. h. 10. 
umum/sekuler yang menyebabkan dikotomi ilmu, sebagaimana dipaparkan di atas. Bukti nyata dari kebutuhan adanya panduan dan model integrasi ilmu ini ditunjukan dengan diselenggarakannya berbagai seminar nasional berkenaan dengan reintegrasi ilmu, sampai pada kebijakan dari pemerintah, seperti kebijakan integrasi madrasah ke dalam sistem pendidikan nasional dalam UUSPN No. 2 tahun 1989, madrasah mengalami perubahan "sekolah agama" menjadi "sekolah umum bercirikan khas islam". Pengintegrasian madrasah ke dalam sistem pendidikan nasional menemukan titik puncaknya pada awal 2000, setelah Presiden RI ke-4 K.H. Abdurrahman Wahid yang mengubah struktur kementrian pendidikan dari "Departemen Pendidikan dan Kebudayaan menjadi "Departemen Pendidikan Nasional".Berdasarkan Hal itu Abdurrahman Wahid menggulirkan ide "pendidikan satu atap" sistem pendidikan nasional dan memiliki status serta hak yang sama. Inilah yang diharapkan dan mengakhiri dikotomi "pendidikan umum" dan "pendidikan Islam". ${ }^{6}$

Proses pendidikan dalam kegiatan pembelajaran atau kegiatan dalam kelas akan berjalan dengan lancer, kondusif dan interaktif apabila dilandasi dengan kurikulum yang baik dan benar. Pendidikan bisa dijalankan dengan baik ketika kurikulum dapat menjadi penyangga utama dalam kegiatan pembejaran, sehingga akan mendapatkan hasil yang optimal. Dengan kurikulum yang mengandung banyak unsur konstruktif, maka akan dapat membuka

${ }^{36}$ Ali M dan Luluk Y. R. 2004. Paradigma Pendidikan Universal di Era Modern dan Post-Modern; Mencarai "Visi Baru" atas "Realitas Baru" Pendidikan Kita. Jakarta: Media Press. h. 267-274. mindset peserta didik yang progresif dan membangunkesadarankritisterhadaprealita sosial. ${ }^{37}$ Kurikulum merupakan rencana tertulis yang berisi tentang gagasan-gagasan dan ide-ide yang telah dirumuskan oleh pengemban kurikulum. Kurikulum itulah yang selanjutnya menjadi pedoman guru dalam melaksanakan proses pembelajaran di dalam kelas. Dengan demikian sistem kurikulum yang digunakan atau sistem pembelajaran yang dilaksanakan oleh guru pada dasarnya merupakan implementasi dari kurikulum. ${ }^{38}$ Secara garis besar pada bagian ini akan dibahas mengenai landasan penyusunan kurikulum, desain kurikulum yang berorientasi pada materi pelajaran, alasan mengapa menggunakan kurikulum integrasi dan pengembangan kurikulum di sekolah. Hal ini dikaitkan dengan aspekaspek pembelajaran yang akan dicapai.

Cerminan kurikulum Islamiharus memuat prinsip: a). Mengandung nilai kesatuan dasar bagi persamaan nilai Islam pada setiap waktu dan tempat; b). mengandung nilai kesatuan kepentingan dalam mengembangkan misi ajaran Islam; c). mengandung materi yang bermuatan pengembangan spiritual, intelektual dan jasmaniah.Hal di atas mengisyaratkan bahwa implementasi kurikulum pendidikan Islami mendapatkan porsi yang strategis dalam melengkapi kurikulum pendidikan umum artinya proses pembelajaran antara pendidikan umum dan agama menjadi poros utama dalam menciptakan sumber daya manusia yang berwawasan imtak dan iptek, sehingga nilai tambah yang didapatkan

${ }^{37}$ Moh Yamin. 2009. Manajemen Mutu Kurikulum Pendidikan. Jogjakarta: Diva Press. h.13-14.

${ }^{38}$ Wina Sanjaya. 2008. kurikulum dan Pembelajaran: Teori dan praktek Pengembangan kurikulum tingkat satuan pendidikan. Jakarta: Kencana Prenada Media Grup. h. 16-17. 
siswa dengan diterapkannya pembelajaran yang berwawasan Islami, mengarahkan siswa pada moral, akhlak dan prilaku yang lebih baik, dapat menumbuhkan minat dan kesadaran siswa yang menghasilkan kecerdasan secara integrated(kecerdasan komplit) antara kecerdasan Intelektual (IQ), kecerdasan Emosional (EQ), kecerdasan Spritiual (SQ), dan berpusat (bersumber) pada kecerdasan Religi (RQ). ${ }^{39}$

Kurikulum pendidikan Islam disekolah dijabarkan dalam tiga komponen utama, yakni: (1) Pembentukan Shakhsiyyah Islāmiyyah (Kepribadian Islam), (2) Thaqofah Islam dan (3) Ilmu Kehidupan (Iptek dan Keahlian).

Tabel 3: Tabel Struktur dan performa Komponen Kurikulum

\begin{tabular}{|c|c|c|c|c|c|}
\hline $\begin{array}{l}\text { Jenjang } \\
\text { Pendidikan }\end{array}$ & \multirow{2}{*}{ TK } & \multirow{2}{*}{ SD } & \multirow{2}{*}{ SMP } & \multirow{2}{*}{ SMU } & \multirow{2}{*}{ PT } \\
\hline $\begin{array}{l}\text { Komponen } \\
\text { Materi }\end{array}$ & & & & & \\
\hline $\begin{array}{l}\text { Shakhsiyyah } \\
\text { Islāmiyyah }\end{array}$ & \multicolumn{2}{|c|}{ Dasar-dasar } & \multicolumn{3}{|c|}{$\begin{array}{l}\text { Pembentukan Dan } \\
\text { Kematangan }\end{array}$} \\
\hline \multirow{5}{*}{$\begin{array}{l}\text { Thaqofah } \\
\text { Islam }\end{array}$} & & & & & 5 \\
\hline & & & & \multirow[t]{4}{*}{4} & \\
\hline & & & 3 & & \\
\hline & & 2 & & & \\
\hline & 1 & & & & \\
\hline \multirow{5}{*}{$\begin{array}{l}\text { Ilmu } \\
\text { Kehidupan }\end{array}$} & & & & \multirow{5}{*}{4} & 5 \\
\hline & & & & & \\
\hline & & & \multirow[t]{3}{*}{3} & & \\
\hline & & \multirow[t]{2}{*}{2} & & & \\
\hline & 1 & & & & \\
\hline
\end{tabular}

Sebagaiman yang tercermin dalam tabel diatas, selain muatan penunjang proses pembentukan Shakhsiyyah Islāmiyyah

${ }^{39} \mathrm{Ali}$ M dan Luluk Y. R. 2004. PAradigma Pendidikan Universal di Era Modern dan Post-Modern; Mencarai "Visi Baru" atas "Realitas Baru" Pendidikan Kita. Jakarta: Media Press. h. 267-274. yang secara terus menerus diberikan pada tingkat TK-SD dan SMP-SMU-PT, muatan Thaqofah Islam dan Ilmu kehidupan (Iptek dan Keahlian) diberikan secara bertingkat sesuai dengan daya serap dan tingkat kemampuan peserta didik berdasarkan jenjang pendidikannya masing-masing.

Pada tingkat dasar atau menjelang usia baligh (TK dan SD), susunan struktur kurikulum sedapat mungkin bersifat mendasar, umum, berpadu dan merata bagi semua peserta didik yang mengikutinya. yang termasuk dalam materi dasar ini antara lain: pengenalan al-Qur'ān dari segi harfiah dan bacaan; prinsip-prinsip agama; mambaca; menulis dan menghitung; prinsip bahasa Arab; menulis halus; sirah Rasul dan Khulafaur Rasyidin serta berlatih berenang dan menunggang kuda. Model-model pembelajaran yang cocok untuk diaplikasikan kedalam pelajaran PAI menurut penulis antara lain: Model connected, sequenced dan integrated.

\section{Model Connected (Terhubung)}

Model connected merupakan model pelajaran terpadu yang menghubungkan atau mengkaitkan antara topik atau konsep atau skill yang satu dengan yang lainnya. Penghubungan ini hanya dapat dilakukan dalam satu bidang studi/mata pelajaran dan tidak untuk dihubungkan dengan mata pelajaran lain.

Pengintegrasian ide-ide yang di pelajari tersebut dalam satu semester dengan semester berikutnya menjadi satu kesatuan yang utuh. Jika diilustrasikan dalam gambar dilihat pada skema di bawah ini: 
Gambar 1: Pembelajaran Model Connected

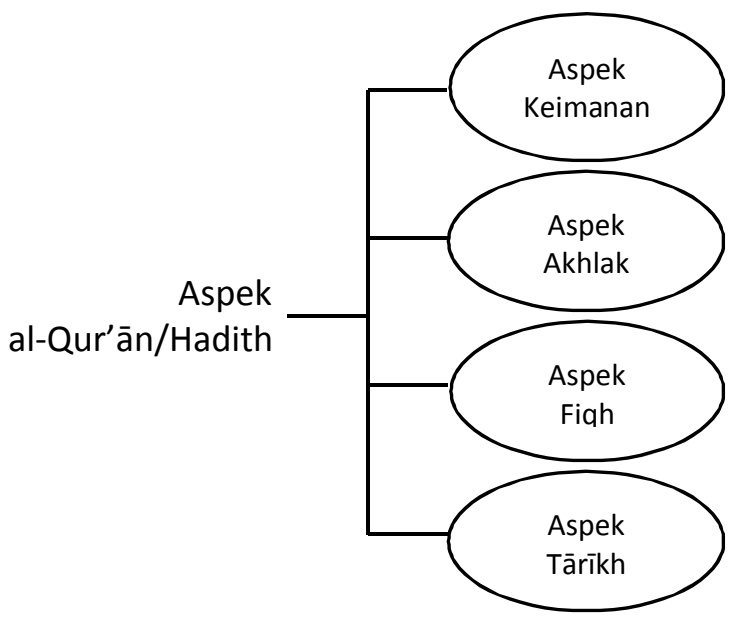

Implementasi dari gambar tersebut di atas memberikan kejelasan, misalnya, Ketika guru PAI menjelaskan Q.S. al-Baqarah: 30

Ingatlah ketika tuhanmu berfirman kepada para malaikat sesungguhnya aku hendak menjadikan seorang khalifah di muka bumi ini.

Indikator atau kompetensi yang ingin dicapai tidak hanya sebatas pada penguasaan peserta didik dalam membaca dengan fasih, melafalkan arti, mengidentifikasi tajwid, menyimpulkan isi kandungan ayat dan menunjukan perilaku yang mencerminkan isi kandungan surat al-baqarah: 30 tetapi lebih luas dari itu khususnya dalam penafsiran atau isi kandungan ayat.

Ayat tersebut dapat dihubungkan dengan aspek keimanan dengan menjelaskan sifat-sifat Allah, seperti sifat-sifat Allah al-khāliq (maha pencipta) al-mālik (maha menguasai), penjelasan tersebut sekaligus dapat dikaitkan dengan aspek akhlak dengan kompetensi yang dicapai lebih menekankan kepada setiap muslim agar menyadari akan tugas dan kedudukannya sebagai seorang makhluk yang berkewajiban untuk menyambah kepada sang khaliq dengan cara istiqomah dan berpengharapan (rāja)segala apa yang diinginkan dengan melalui ibadah Di antaranya berdo'a dan berikhtiar. Bagaimana seorang muslim menyembah kepada Allah maka dapat dikaitkan dengan aspek fiqh baik yang dengan berkaitkan dengan ibādah makhdah maupun ghairu makhdah. Di samping itu juga dapat dikaitkan dengan sejerah umat-umat dahulu sebelum umat Nabi Muhammad SAW yang mendapatkan azab dari Allah, karena mereka mengingkari akan kekuasaan Allah yang ada di seluruh alam semesta dalam cara menentang ajaran-ajaran yang dibawa oleh nabi dan rasul.

\section{Model Sequenced (Berurutan)}

Model sequenced merupakan model pembelajaran yang mencoba untuk melakukan pemanduan melalui urutan topik dan konsep pada masing-masing materi pelajaran yang di hubungkan berdasarkan kesamaan ide tau konsep tersebut kemudian disajikan dengan secara pararel atau berbarengan dengan waktu yang bersamaan. Maurer sebagai dikutip oleh Saefudin Sabda dengan istilah the correlated event sequence model. Saat guru PAI mangajarkan suatu aspek tertentu, maka ia menyusun urutan topik dan aspek tertentu yang kemudian dimasukan pada pada topik-topik dan aspek lain yang terkandung dalam mata pelajaran PAI kedalam urutan penyampaian pembelajaran, karena adanya relevansi antara topik-topik tersebut. Artinya bahwa satu aspek mata pelajaran membawa serta aspek-aspek lain dan sebaliknya. Misalnya ketika guru PAI mengajarkan Q.S al-Baqarah: 148 yang menyangkut masalah 
kompetisi dalam kebaikan dimulai dari aspek al-Qur'ān, kemudian memasukan aspek keimanan, akhlak, fiqh dan tārīkh kebudayaan Islam. Model sequenced dapat dilihat pada gambar dibawah ini:

Gambar 2: Pembelajaran Model Sequenced

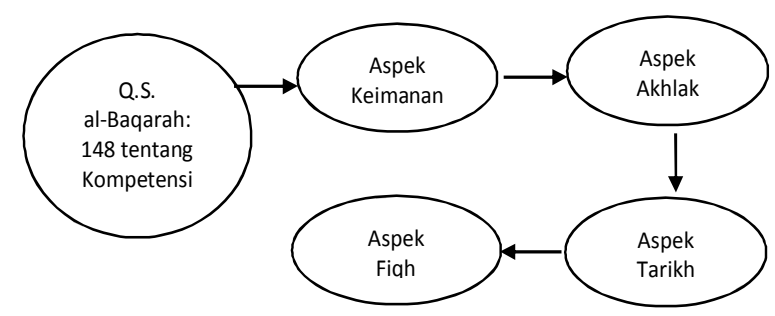

Pada pembahasan PAI aspek al-Qur'ān Q.S al-Baqarah: 148 (tentang kompetisi dalam kebaikan)

"Dan bagi tiap-tiap umat ada kiblatnya (sendiri) yang ia menghadap kepadanya, maka berlomba-lombalah kamu dalam (membuat kebaikan).

Maka kompetensi yang akan dicapai oleh peserta didik adalah dimulai dari aspek membaca dengan fasih, mengidentifikasi tajwid, menjelaskan isi kandungan, kemudian mengamalkan isinya. Dalam kaitannya dengan isi kandunagan ayat atau pengamalan isi ayat, maka guru PAI daapat memasukan secara topik-topik yang lain relavan.

Aspek lain yang pararel dan dapat dimasukan dalam pembahasan, yaitu aspek keimanan dengan mengembangkan topik tentang iman kepada rasul-rasul Allah, yaitu meneladani sifat-sifat rasul yang empat yaitu: Sidiq, amanah, tabligh, fatonah dalam perilaku sehari-hari disertai dengan penjelasan fungsi iman kepada rasul- rasul Allah. Kemudian aspek akhlak dapat mengembangkan tentang topik kebiasaan berperilaku terpuji seperti husnu zan, membiasakan bertaubat kepada Allah setiap melakukan perbuatan dosa dan lain sebagainya. Sebagai implementasi dari bentuk-bentuk ibadah yang menjadikan seorang muslim itu beriman kepada rasulrasul Allah dan membiasakan berkompetisi dalam kebaikan dengan melalui aspek fiqh dengan mengembangkan pentingnya pengamalan ibadah (zakāt, infāq dan șadaqah) sebagai pendekati diri kepada Allah dan antar sesama manusia. Aspek lain adalah tarikh mengembangkan topik tentang perilaku para sahabat Rasulullah yang mempunyai komitmen tinggi dalam memperjuangkan agama Islam masa-masa awal, tidak hanya sebatas perjuangan dengan harta bahkan nyawapun mereka siap berkorban demi kejayaan Islam.

\section{Model Integrated}

Makna integrasi dalam model pembelajaran intergrated berarti berpaduan, kordinasi, kebulatan dan keutuhan. Model pembelajaran integrasi meniadakan batasbatas antara berbagai mata pelajaran dan menyajikan bahan pelajaran dalam bentuk unit dan keseluruhan yang saling tumpang tindih sebagai titik-tolak kajianya. ${ }^{40}$ Dengan

${ }^{40}$ Untuk menentukan pokok-pokok manakah yang dapat dijadikan unit yang akan dipelajari oleh peserta didik dapat menggunakan pertanyanpertanyan sebagai berikut: (1) Apakah pokok itu dibangkitkan oleh minat, kebutuhan dan pengalaman peserta didik dalam kelas ? (2) Apakah bahan pelajaran itu sesuai dengan taraf dengan kematangan peserta didik ? (3) Cukupkah kesempatan dalam pelajaran ini untuk merangsang peserta didik berpikir dan berbuat banyak mungkin ? (4) Apakah sarana dan prasarana tersedia untuk melaksanakan 
demikian, terlihat jelas bahwa semua mata pelajaran/bidang studi telah terpadu sebagai satu kesatuan yang bulat atau utuh. Model ini merupakan salah satu model pembelajaran terpadu yang menggunakan pendekatan antar bidang studi. ${ }^{41}$ Sekuen materi dalam model ini didesain dengan mencari konsep-konsep, skills dan attitudes tertentu yang operlaping di berbagai mata pelajaran/bidang studi, kemudian dibahas pada suatu masing-masing mata pelajaran/ bidang studi yang terkait. ${ }^{42}$ Pada model ini tema dan tema yang berkaitan dan tumpang tindih merupakan hal terakhir yang ingin dicari dan dipilih oleh guru dalam tahap perencanaan program.

Sedangkan pengintegrasian materi antarbidang studi, yaitu mengkaji sesuatu tema ditinjau dari berbagai aspek yang tidak hanya pada aspek-aspek yang terdapat pada mata pelajaran PAI, tetapi mata pelajaranmata pelajaran yang lainnya. Dalam konteks pengembangan ilmu dan teori biasa disebut dengan multidisiplin. ${ }^{43}$ Karena melibatkan banyak disiplin keilmuan atau mata pelajaran/bidang studi, maka dapat dilakukan dengan team teaching. Team teaching dimaksud sebagai saran sharing atau bertukar pikiran dengan mengenai informasi atau konsep antar guru-guru

unit?. Lihat S. Nasution. 2008. Asas-asas kurikulum, Cet. VIII. Jakarta: Bumi Aksara. h.207-208.

${ }^{41}$ Trianto, Model Pembelajaran Terpadu; Konsep, Strategi dan impletasinya dalam KTSP, 43.

${ }^{42}$ Robin forgaty, the mindful school: how to curricula, 76. Bandingkan Saefudin sabda, Desain Pengembangan dan Implementasi Model Kurikulum Terpadu Iptek dan Imtak, 83.

${ }^{43}$ Multidisiplin adalah cara kerjanya seorang ahli suatu disiplin ilmu yang berupaya membangun disiplin ilmunya dengan berkonsulasi pada ahli disipli lain. Lihat Muhaimin, Nuansa Baru Pendidikan Islam; Mengurai Benang Kusut Dunia Pendidikan, 181. mata pelajaran/bidang studi yang terkait, sehingga pembahasan yang disampaikan menjadi holistik. Implikasi dilapangan pelajaran terpadu ini di sajikan atau diajarkan dengan cara team; satu topik pembelajaran dilakukan oleh lebih dari seorang guru (team teaching). ${ }^{44}$ Tema-tema yang berkaitan tumpang tindih merupakan hal yang terakhir yang ingin dicari dan dipilih oleh guru dalam tahap perencanaaan program. Konsep-konsep, ketrampilan dan sikap di ajarkan dalam satu semester dari beberapa mata pelajaran/bidang studi selanjutnya dipilih beberapah konsep, ketrampilan dan sikap yang memiliki keterhubungan yang erat dan tumpang tindih Di antara berbagai bidang studi. ${ }^{45}$

Dengan demikian, untuk membangun pendidikan integratif diperlukan Konsep pendidikan Islam yang dirancang sebagai pendidikan yang benar-benar holistik dan terpadu. Holistik dalam hal visi, isi, struktur dan proses. Terpadu dalam pendekatannya baik terhadap kurikulum (bagaimana dan apa yang harus diajarkan), pengetahuan yang menyatupadukan dengan praktik, aplikasi dan pelayanan. Hal tersebut bisa terealisasi dengan mengadopsi pemikiran Mullā Sadrā tentang Waḥdah al-Wujū $d^{46}$ yang tertuang

${ }^{44}$ Trianto, Model Pembelajaran Terpadu; Konsep, Strategi dan impletasinya dalam KTSP, 117.

${ }_{45}$ Ketrampilan-ketrampilan belajar menurut forgaty meliputi ketrampilan berpikir (Thinking skil), ketrampilan sosial (Social skil) dan ketrampilan mengorganisir (Organizing skil). Lihat Robin forgaty, The Mindful School; How to Integrate The Curricula, 77.

${ }^{46}$ Penjelasan Mullā Sadrā tentang waḥdah alwujūd yang kemudian menjadi basis integraasi ilmu agama dan ilmu umum ini, tampaknya telah ia adopsi dari ajaran Suhrawardì Al-Maqtūl (w.1191) tentang cahaya. Menurutnya, cahaya pada hakikatnya adalah satu, tetapi ia menjadi berbeda-beda tingkat dan intensitasnya beda tingkat dan intensitasnya karena adanya barzakh- 
dalam prinsip Tauhìd. Pendidikan holistik inilah mencakup konsep filosofis maupun metodologis yang terstruktur dan koheren kepada pemahaman terhadap dunia dan seluruh aspek kehidupan. Ilmu-ilmu agama yang berbasis pada wahyu (al-Qur'ān dan alHadith) sebagai ayat-ayat qauliyyah dan ilmuilmu umum berbasis pada akal, penalaran terhadap fenomena alam sebagai ayat-ayat kauniyyah. Seluruh metode yang diterapkan dalam ilmu umum dan agama (panca indera, rasio, intuisi dan wahyu) secara sinergis diterapkan dalam menemukan kebenaran.

\section{PENUTUP}

Berdasarkan penjelasan dan uraian yang tersebutdiatas, maka dapat disimpulkan beberapa hal sebagai berikut:

Pertama, bahwa integrasi ilmu dan agama adalah integrasi yang bersifat integratif-holistik yaitu, eksistensi ilmu umum dan ilmu agama saling bergantung satu sama lain. Eksistensi (wujūd) yang ada pada pelajaran umum dan agama dengan segala bentuk dan karakternya pada hakikatnya adalah satu dan sama, yang membedakan satu dari yang lainnya hanyalah gradasinya (tashkik al-wujūd) yang disebabkan oleh perbedaan dalam esensinya. Adapun konsep integrasi ilmu dan agama dalam perspektif Mullā Sadrā memiliki landasan ontologis, epistemologis dan aksiologis.

Kedua, Dengan mengadopsi pemikiran Mullā Sadrā tentang integrasi keilmuan yang

barzakh (barāzikh) yang menyela di antaranya. Oleh karena itu Di antara pelajaran umum dan agama pada esensinya adalah satu yang membedakan hanyalah tingkatannya saja, sehingga tidak dikenal dengan adanya dikotomi ilmu pengetahuan.Lihat Mulyadhi Kartanegara. 2005. Integrasi Ilmu; Sebuah Rekonstruksi Holistik. Bandung: Arasy Mizan. h. 36. tertuang dalam prinsip Tauhid, maka untuk membangun pendidikan integratif diperlukan Konsep pendidikan Islam yang dirancang sebagai pendidikan yang benar-benar holistik dan terpadu. Holistik dalam hal visi, isi, struktur dan proses. Terpadu dalam pendekatannya baik terhadap kurikulum (bagaimana dan apa yang harus diajarkan), pengetahuan yang menyatupadukan dengan praktik, aplikasi dan pelayanan. Pendidikan holistik inilah mencakup konsep filosofis maupun metodologis yang terstruktur dan koheren kepada pemahaman terhadap dunia dan seluruh aspek kehidupan. Ilmuilmu agama yang berbasis pada wahyu (alQur'ān dan al-Ḥadith) sebagai ayat-ayat qauliyyah dan ilmu-ilmu umum berbasis pada akal, penalaran terhadap fenomena alam sebagai ayat-ayat kauniyyah. Seluruh metode yang diterapkan dalam ilmu umum dan agama (panca indera, rasio, intuisi dan wahyu) secara sinergis diterapkan dalam menemukan kebenaran. 


\section{SUMBER BACAAN}

Amiruddin, M. Hasbi dan Husen, Usman (2007): Integrasi Ilmu dan Agama. Banda Aceh, Yayasan PENA.

Azra, Azyumardi (2002): Historiografi Islam Kontemporer: Wacana, Aktualitas dan Aktor Sejarah. Jakarta, Gramedia Pustaka Utama.

Baharuddin, Umiarso, Minarti, Sri (2011): Dikotomi Pendidikan Islam; Historisitas dan Implikasi pada Masyarakat Islam. Bandung, PT Remaja Rosdakarya.

Dahlan, Abdul Aziz (2012): Teologi, Filsafat, Tasawuf dalam Islam. Jakarta, Ushul Press.

Fadjar, A. Malik (1999): Reorientasi Pendidikan Islam. Jakarta, Yayasan Pendidikan Islam Fajar Dunia.

Forgaty, Robin (1991): The Mindful School; How to Integrate The Curricula. IIIionis, IRI/Skylight Publishing Inc.

Hitti, Philip K, (1974): History of The Arab. London, Macmilan Press Ltd..

Kartanegara, Mulyadhi (2005): Integrasi Ilmu; Sebuah Rekonstruksi Holistik. Bandung, Arasy Mizan.

- (2005): Menembus Batas Waktu Panorama Filsafat Islam. Bandung, PT Mizan Pustaka.

Khalaf, Abd. Wahab (1978). Cet. II: Ilmu Ushul Fiqh. Beirut, Dar al-Fikr.

Ma'arif, Syamsul (2007): Revitasi Pendidikan Islam. Yogyakarta, Graha Ilmu.

Mirza, Muhammad R. dan Siddiqi, Muhammad Iqbal (1986) Cet.1: Muslim Contribution to Science. Pakistan, Kazi Publications.
Muhaimin (2006): Nuansa Baru Pendidikan Islam: Mengurai Benang Kusut Dunia Pendidikan. Jakarta, RajaGrafindo Persada.

Mulyanto, "Islamisasi Ilmu Pengetahuan," dalam Moeflich Hasbullah (2000) Cet. 1: Gagasan dan Perdebatan Islamisasi Ilmu Pengetahuan. Jakarta, LSAF, Iris, Cidesindo.

Mustofa (2007): “Tauhid: Akar Tradisi Intelektual Masyarakat Muslim" dalam Intelektualisme Islam, Melacak Akar-akar Integrasi Ilmu dan Agama, editor Lutfi Mustofa dan Helmi Syaifuddin. UIN Malang: LKQS.

Nasr, Seyyed Hossein (1968): Three Muslim Sages. Cambridge, Harvard University Press.

(1981): Islamic Life and Thought. Albany, SUNNY Press.

Nasution. S. (2008) Cet. VIII: Asas-Asas Kurikulum. Jakarta: Bumi Aksara.

Nasution, Harun (1979): Islam Ditinjau dari berbagai Aspeknya. Jakarta, UI Press.

Nasution, Harun (1978), Cet. 1: Teologi (Ilmu Kalam). Jakarta, UI Press.

Nata, Abuddin Suwito., Abdillah, Masykuri., Arief, Armai (2005): Integrasi Ilmu Agama dan Ilmu Umum. Jakarta, PT RajaGrafindo Persada.

Nur, Syaifan (2002): Filsafat Wujud Mullā Sadrā. Yogyakarta, Pustaka Pelajar.

Pals, Daniel L.(2001): Seven Theories OfReligion, terj. Ali Noer Zaman. Yogyakarta, Penerbit Kalam.

Poeradisastra (1980): Sumbangan Islam terhadap Peradaban Eropa dan Barat. Jakarta, P3M.

Rusydi, M. Artikel (2006): "Wacana Dikotomi Ilmu dalam Pendidikan Islam dan Pengaruhnya". Jurnal: Al Banjari, Vol.5, No.9.

S. Suriasumatri, Jujun (1999): Ilmu dalam Perspektif. Jakarta, Yayasan Obor Indonesia. 
Sadrā, Mullā (1981): Al-Hikmat Al-Muta'āliyah fi'l Asfar Al-'Aqliyah Al-Arba'ah. Beirut, Dār Ihyā wa al-Turāts Al'Arabì.

(tth): Al-Masā’il al-Qudsiyyah; Mutashābihāt al-Qur'ān. Resāle, Masyhad University Press.

Sanjaya, Wina (2008): kurikulum dan Pembelajaran: Teori dan praktek Pengembangan kurikulum tingkat satuan pendidikan. Jakarta, Kencana Prenada Media Grup.

Trianto, Model Pembelajaran Terpadu: Konsep, Strategi, dan Implementasinya dalam KTSP. Jakarta, Bumi Aksara.
Yamin, Moh (2009): Manajemen Mutu Kurikulum Pendidikan. Jogjakarta, Diva Press.

Zaini, Syahminan (1989): Integrasi Ilmu dan Aplikasinya menurut Al-Qur'an. Jakarta, Kalam Mulia.

Zainuddin, M. (2011): "Paradigma Pendidikan Islam Holistik," Jurnal Ulumuna, Vol. XV, No. 1: 85. 